\title{
FAKTOR PENGHAMBAT DAN PENDUKUNG BADAN USAHA MILIK DESA PADA KAWASAN PERTAMBANGAN EMAS DI SUMBAWA BARAT
}

\author{
Ibrahim, ${ }^{1}$ Iwan Tanjung Sutarna, ${ }^{2}$ Ibrahim Abdullah, ${ }^{3}$ Kamaluddin, ${ }^{4}$ dan Mas'ad $^{5}$ \\ ${ }^{1,4,5}$ Fakultas Keguruan dan Ilmu Pendidikan, \\ ${ }^{2,3}$ Fakultas Fakultas Ilmu Sosial dan Ilmu Politik Universitas Muhammadiyah Mataram, 831273 \\ E-mail: ibrahimali.geo@email.com;
}

\begin{abstract}
ABSTRAK. Keberadaan Badan Usaha Milik Desa (BUMDes) pada perdesaan kawasan pertambangan emas memiliki nilai tambah dalam mengembangkan usaha. Namun pada kenyataannya program BUMDes belum mampu berbuat banyak dalam menanggulangi kemiskinan di sekitarnya. Penelitian ini bertujuan untuk menganalisis faktor penghambat dan pendukung Badan Usaha Milik Desa (BUMDes) pada kawasan pertambangan emas di Sumbawa Barat. Penelitian ini menggunakan pendekatan kualitatif deskriptif. Pengambilan data dilakukan pada perdesaan kawasan pertambangan emas Kabupaten Sumbawa Barat. Kecamatan yang termasuk dalam kawasan pertambangan emas yaitu: Kecamatan Jereweh, Maluk dan Sekongkang. Teknik pengumpulan data menggunakan wawancara, dokumentasi, dan observasi dengan subyek penelitian dari pihak desa, pengelola BUMDES, masyarakat penerima manfaat program dan instansi terkait. Validitas data menggunakan teknik triangulasi. Analisis data menggunakan reduksi, display, verifikasi dan kesimpulan. Hasil penelitian menunjukan bahwa factor penghambat BUMDes pada kawasan pertambangan emas adalah 1) faktor anggaran, 2) factor Sumberdaya Manusia pengelola, dan 3) Terbatasnya dukungan dari pihak swasta,. Factor pendukung sebagai penguat adalah 1) komitmen pemerintah, dan 2) tersedianya potensi Sumber Daya Alam. Keberadaan factor penghambat karena banyak program pemerintah yang dibiayai. Diperlukan kerja keras pengelola BUMDes dalam mengembangkan usaha melalui program-program kreatif dan inovatif untuk dapat berdaya saing.
\end{abstract}

Kata kunci: Penghambat; pendukung; BUMDes; Kawasan Tambang

\section{SUPPORTING FACTORS AND SUPPORT OF VILLAGE BUSINESS ENTITIES IN THE GOLD MINING AREA IN WEST SUMBAWA}

ABSTRACT. The existence of Village-Owned Enterprises (BUMDes) in rural gold mining areas has added value in developing business. But in reality, the BUMDes program has not been able to do much in tackling poverty around it. This study aims to analyze the inhibiting and supporting factors of BUMDes in the gold mining area in West Sumbawa. This research uses a descriptive qualitative approach. Data was collected in the rural gold mining area of West Sumbawa Regency. The sub-districts included in the gold mining area are: Jereweh, Maluk and Sekongkang Districts. Data collection techniques using interviews, documentation, and observation with research subjects from the village, BUMDES managers, program beneficiary communities, and related agencies. Data validity uses triangulation techniques. Data analysis uses reduction, display, verification, and conclusion. The results showed that the inhibiting factors of BUMDes in the gold mining area were 1) economic factor, 2) Human Resources management factors, and 3) Limited support from the private sector. Supporting elements as reinforcement are 1) government commitment, and 2) the availability of natural resources potential - the existence of inhibiting factors because many government programs are funded. BUMDes manager hard work is needed in developing businesses through creative and innovative programs to be competitive.

Key words: Inhibitors; supporters; BUMDes; Mining Area

\section{PENDAHULUAN}

Keberadaan BUMDes sebagai lembaga ekonomi desa menjadi salah satu program desa sebagai sarana untuk meningkatkan Pendapatan Asli Desa (PADes). Peranan BUMDes sebagai instrumen penguatan otonomi desa dan juga sebagai instrumen kesejahteraan masyarakat. Pemerintah desa memiliki kekuasaan dalam mengembangkan potensi sesuai dengan kemampuan desa. Keterlibatan masyarakat dalam pengelolaan BUMDes akan dapat mendorong dibukanya usaha baru dan dapat mengurangi tingkat mengangguran.

Peraturan Menteri Desa, Pembangunan Daerah Tertinggal, dan Transmigrasi Nomor 4 Tahun 2015 tentang Pendirian, Pengurusan, dan Pengelolaan, dan pembubaran Badan Usaha Milik Desa dalam pasal 3 menyebutkan bahwa tujuan pendirian BUMDes adalah a. meningkatkan perekonomian Desa; b. mengoptimalkan aset Desa agar bermanfaat untuk kesejahteraan Desa; c. meningkatkan usaha masyarakat dalam pengelolaan potensi ekonomi Desa; d. mengembangkan rencana kerja sama usaha antar desa dan/atau dengan pihak ketiga; e. menciptakan peluang dan jaringan pasar yang mendukung kebutuhan layanan umum warga; f. membuka lapangan kerja; g. meningkatkan kesejahteraan masyarakatmelalui perbaikan pelayanan umum, pertumbuhan dan pemerataan ekonomi Desa; dan h. meningkatkan pendapatan masyarakat Desa dan Pendapatan Asli Desa.

Keberadaan BUMDes diperlukan peran aktif masyarakat dalam mengelola program. Tingkat partisipasi masyarakat baik pada tahap perencanaan, pelaksanaan, pengambilan manfaat, dan evaluasi dapat dikategorikan 
positif artinya partisipasi masyarakat dinilai cukup aktif (Saepudin dkk, 2018).

Peran aktif masyarakat sebagai modal utama dalam mengembangkan usaha. Keberadaan BUMDes akan mampu mencapai tujuan sebagai bagian dalam pemberdayaan dalam meningkatkan ekonomi masyarakat. Sasaran program berorientasi pada masyarakat dengan tingkat kemiskinan rendah.

Kondisi dan karakteristik masyarakat desa nan miskin beragam. Menurut Sutopo (2017) menunjukkan bahwa kondisi kemiskinan demikian ini disebabkan karena beberapa hal mendasar, yaitu: (1) mayoritas warga sebagai petani memiliki derajat ketergantungan yang tinggi terhadap tanah yang menjadi sumber penghidupan mereka di bidang pertanian, (2) dalam hal produksi ruang pertanian yang sangat bergantung pada iklim, (3) tingkat hasil produksinya tidak cukup memberikan keuntungan bagi pemenuhan kebutuhan hidup mayoritas warga sebagai buruh petani karena ketiadaan kepemilikan lahan pertanian karena lahan secara terbatas hanya dimiliki oleh segelintir warga, dan (4) ketergantungan mayoritas warga terhadap pemilik lahan menjadikan struktur sosial yang erat kaitannya dengan lahan, sehingga tercipta kemiskinan sebagai bentuk morfologi sosial.

Kabupaten Sumbawa Barat sebagai penghasil Sumber Daya Alam yang melimpah dan mampu memberikan memanfaatkan potensi ini guna kepentingan pelaksanaan pembangunan daerah khususnya di bidang pembangunan dan penyediaan infrastruktur dasar.

Selain potensi tersebut Kabupaten Sumbawa Barat memiliki potensi yang belum dikelola secara maksimal untuk meningkatkan kesejahteraan masyarakat. BUMDes sebagai lembaga ekonomi mikro pada tingkat desa memilikipeluang dalammengembang ekonomi perdesaan. Program BUMDes belum menunjukan konstribusi dalam peningkatan akses terhadap pelayanan jasa keuangan pada tingkat perdesaan sebagai proses pumutusan mata rantai kemiskinan.

Berdasarkan paparan diatas, penelitian ini bertujuan mengkaji faktor penghambat dan pendukung Badan Usaha Milik Desa pada kawasan pertambangan emas di Sumbawa Barat

\section{METODE}

Pengambilan data dalam penelitian dilakukan pada perdesaan kawasan pertambangan emas Kabupaten Sumbawa Barat. Lokasi penelitian ini mewakili 3 (tiga) kecamatan yang termasuk dalam kawasan pertambangan emas terdiri dari: Kecamatan Jereweh, Maluk dan Sekongkang.

Data diperoleh dari tiga sumber yaitu: pertama, akan digali dari pengamatan langsung dari proses aktivitas pengelola BUMDes; kedua, diperoleh melalui informan (narasumber) yang terlibat langsung dilapangan pada program BUMDes; ketiga, informasi stakeholders pada pihak desa masing-masing yang memahami kondisi masyarakat dan pelaksanaan program BUMDes serta instansi terkait.

Pengumpulan data yang dilakukan dalam penelitian ini dengan menggunakan 4 (empat) cara antara lain: observasi, wawancara, perekaman dan pencatatan. Validitas data menggunakan teknik triangulasi sumber.

Analisis data menggunakan model analisis interaktif yaitu analisis dengan menggunakan reduksi data, display data dan kesimpulan.

\section{HASIL DAN PEMBAHASAN}

\section{Faktor Penghambat Dan Pendukung Badan Usaha Milik Desa}

Undang-Undang Nomor 32 Tahun 2004 tentang Pemerintahan Daerah, desa dapat mendirikan badan usaha sesuai dengan potensi dan kebutuhan desa. Dijelaskan juga dalam Peraturan Pemerintah Nomor 72 Tahun 2005 tentang Desa bahwa untuk meningkatkan pendapatan desa dan masyarakat, pemerintah desa dapat mendirikan Badan Usaha Milik Desa sesuai dengan kebutuhan dan potensi desa.

Hal tersebut berarti pembentukan BUMDes di dasarkan pada kebutuhan, potensi, dan kapasitas desa, sebagai upaya peningkatan kesejahteraan masyarakat. Perencanaan dan pembentukan BUMDes adalah atas prakarsa masyarakat desa.

BUMDes didirikan berdasarkan kebutuhan dan potensi desa yang merupakan prakarsa masyarakat desa. Artinya usaha yang kelak akan diwujudkan adalah digali dari keinginan dan hasrat untuk menciptakan sebuah kemajuan di dalam masyarakat desa.

Hasil penelitian Meigawati (2018) menjelaskan bahwa menunjukkan bahwa implementasi program BUMDes belum berjalan dengan baik. Faktor penghambatnya yaitu dari kurangnya sumberdaya manusia dan finansial serta lemahnya sosialisasi Program BUMDes kepada masyarakat. Adapun faktor pendukungnya yaitu Adanya partisipasi masyarakat dalam mengikuti program BUMDes melalui kegiatan simpan pinjam.

Pernyatan ini diperkuat dari hasil penelitian Ibrahim dan Sutarna (2018) menjelaskana bahwa BUMDES pada perdesaan kawasan pertambangan emas belum berhasil secara total dalam peningkatan kesejahteraan masyarakat dari unit-unit program BUMDES yang ada. BUMDES Kawasan pertambangan emas memiliki kelebihan yaitu: a) mudahnya akses keuangan dan b) peningkatan ekonomi rumah tangga. Kelemahan: a) Sumberdaya Manusia pengelola dan b) rencana usaha rendah. Perlu adanya 
partitipasi aktif dari masyarakat dalam menjalan program BUMDes menuju ekonomi berkemajuan.

Selain faktor kelebihan secara umum keberadaan BUMDes dapat mengurangi kelemahan dengan berbagai usaha dilakukan dalam mensejahterahkan anggota. Pelaksanaan program BUMDes menitikberatkan pada kawasan pertambangan emas Kabupaten Sumbawa Barat memiliki faktor penghambat dan pendukung dalam meningkatkan perekonomian masyarakat perdesaan sekitar.

\section{Faktor Penghambat}

\section{1. faktor Anggaran}

Keberadaan BUMDes dalam meaksanakan program dan usaha tidak bias lepas dari anggaran yang dimiliki. Sebagai lembaga usaha keberadaan modal usaha salah satu nadi untuk hidup dan berkembang. Kesiapan dana usaha terbatas memiliki tingkat kemampuan pengelola usahapun akan mengalami kemunduran.

Keberadaan BUMDes pada masyarakat perdesaan kawasan pertambangan emas di Kabupaten Sumbawa Barat sebagai alternative dalam mengembangkan usaha ekonomi masyarakat. Berdasarkan wawancara mendalam dengan AGT (Pengelola Program BUMDes dasan Anyar) pada tanggal 16 Juli 2019 menyebutkan bahwa keberadaan program BUMDes di desa kami masih terbatas pada uasha penjualan minyak tanah dan bensin. Selain program ini kami juga pernah ada program simpan pinjam tapi terkendala dalam pelaksanaannya karena uangnnya sedang di bendahara yang saat ini masih sebagai Tenaka Kerja wanita ke Arab. Keberadaan anggaran yang kami olah masih sangat minim dan usahapun kami sesuai dengan anggaran yang kami miliki.

Hal senada dari wawancara mendalam dengan MIK (Kepala Desa) pada tanggal 16 Juli 2019 menyebutkan bahwa anggaran yang dimiliki desa dalam menjalankan usaha BUMDes ada, namun masih sangat kecil untuk mengembangkan usaha yang besar. Oleh karena itu, diperlukan adanya terobosan dari pengelola BUMDes dalam memilih usaha yang sesuai dengan anggaran yang dimiliki.

Berdasarkan hasil wawancara diatas dapat disimpulkan bahwa keberadaan BUMDes dalam mengelola program usaha di tengah masyarakat masih mengalami kendala terutama terbatasnya anggara yang dimiliki. Menurut Ihsan (2018) menjelaskan bahwa partisipasi masyarakat yang tinggi dalam pelaksanaan kegiatan BUMDes melalui unit-unit usaha yang dimiliki BUMDes dan kelompok-kelompok masyarakat yang bermitra dengan BUMDes. Namun masih terdapat hambatan dan permasalahan yang terjadi dalam pelaksanaan dan pengelolaan BUMDes. Permasalahan yang terjadi adalah adanya potensi desa yang belum bisa dikembangkan melalui BUMDes karena belum adanya modal.
Pernyataan ini diperkuat Rani (2018) menjelaskan bahwa BUMDES sudah cukup berperan dan berkontrbusi bagi masyarakat hanya saja belum dapat dikataan maksimal, yakni masih adanya ketimpangan kesejahteraan antar masyarakat. Hal itu dikarenakan masih banyaknya kendala yaitu seperti kurangnya modal, pengetahuan masyarakat dan kurang maksimalnya kinerja serta manajemen BUMDES itu sendiri.

Pernyatan diatas diperkuat dari hasil penelitian Liow dkk (2019) menjelaskan bahwa penerapan standard oprasional prosedur BUMDes yang kurang maksimal karena belum rampungnya anggaran dasar dan anggaran rumah tangga BUMDes, dan sumber daya yang ada di BUMDes Tondegesan saat ini seperti kompetensi sumber daya manusia, fasilitas dan pendanaan yang masih sangat minim sehingga berakibat pada hambatan dari pengembagan program-program BUMDes kedepannya.

\section{2. faktor Sumber Daya Manusia pengelola}

Otonomi desa merupakan peluang bagi desa dalam mengembang desa sesuai dengan potensi yang dimiliki. Keberadaan BUMDes sebagai instrumen dalam meningkatkan kesejahtera dengan melibatkan masyarakat dalam pengelolaan.

Keterlibatan masyarakat dalam program BUMDes memiliki keterbatasan dalam mengembangkan usaha. Berdasarkan wawancara mendalam dengan SS ( Seksi Bidang Pemberdayaan Ekonomi Masyarakat Dan Tekhnologi Tepat Guna DPMD) pada tanggal 21 Juni 2019 menyebutkan bahwa keterlibatan masyarakat BUMDes sangat terbuka, namun kendala di masyarakat masih rendah pada tingkat SDM pengelola. Usaha dilakukan dari kami dengan mengadakan pelatihan-pelatihan yang mendukung program BUMDes yang sedang kelolah.

Berdasarkan hasil wawancara diatas dapat disimpulkan bahwa keberadaan BUMDes masih membutuhkan dukungan semua pihak dalam meningkatkan sumberdaya manusia pengelola. Menurut Ibrahim dkk (2017) menjelaskan bahwa persebaran program BUMDes di Kabupaten Sumbawa Barat dapat lebih fokus pada program simpan pinjam dibandingkan dengan program lainnya. Program ini belum optimal karena masih rendahnya Sumberdaya Manusia dan enterpreneurshif dan perlu adanya pelatihan pendukung, guna meningkatkan tata kelola BUMDes secara berkelanjutan.

Hal ini diperkuat Ibrahim dkk (2018) karakteristik program Badan Usaha Milik Desa pada perdesaan kawasan pertambangan emas di Kabupaten Sumbawa Barat menitikberatkan pada bidang usaha dari dari simpan pinjam dan tingkat perkembangan usahanya rendah karena tingkat Sumberdaya Manusia dan tanggung jawab pihak desa dalam memanfaatkan program dalam meningkatkan kesejahteraan masyarakat. 
Pernyataan diatas diperkuat hasil penelitian Ibrahim dkk (2017) menjelaskan bahwa keberdaan BUMDes belum mampu memberikan manfaat dalam meningkatkan kesejahteraan masyarakat. Hal ini karena minimnya Sumberdaya Manusia dan tata kelola yang tidak berkelanjutan. Sinergitas pengelolaBUMDes dan masyarakat dalam partisipasi secara aktif dari dalam perencanaan, pelaksanaan hingga evaluasi guna memberikan manfaat keberadaan BUMDes ditengah masyarakat.

\section{Terbatasnya dukungan dari pihak swasta}

Pemberdayaan BUMDes Melalui Kelompok Ekonomi Kewirausahaan Secara Partisipatif adalah untuk mewujudkan kemandirian ekonomi desa melalui pengembangan kelembagaan dan pemberdayaan pengelolaan usaha ekonomi masyarakat yang dilaksanakan dengan keterlibatan masyarakat, pemerintah, dan swasta sehingga semua stake holder didesa berperan optimal dalam menumbuh kembangkan perekonomian desa (Mustanir \& Jusman, 2016a) (Mustanir,Yasin, Irwan, \& Rusdi, 2018) (Mustanir \& Jaya, 2016a) (Mustanir, Abadi, \& Nasri, 2016) (Mustanir \& Darmiah, 2016) (Mustanir \& Lubis, 2017a).

Keterlibatan pihak swasta dalam pengembangan usaha BUMDes akan dapat menumbuhkembangkan usaha secara berkelanjutan. Berdasarkan wawancara mendalam dengan MMT (KAUR Keuangan Desa Goa) pada tanggal 20 Juli 2019 menyebutkan bahwa program BUMDes dengan pendanaan berasal dari desa semata. Namun pada pihak swasta masih terbatas pada programprogram tertentu. Apalagi dengan hadirnya perusahaan swasta baru pengganti PT. Newmont Nusa Tenggara masih belum ada partisipasi terhadap masyarakat sebagai bentuk tanggung jawab social terhadap masyarakat.

Peran swasta dalam pengembangan mesyarakat melalui pendanaan social yang dimilikisebagai bentuk tanggung jawab social pada masyarakat. Menurut The Organization for Economic Coorporation and Development (dalam Ismail Sholihin, 2011) merumuskan CSR sebagai berikut: kontribusi bisnis bagi pembangunan berkelanjutan serta adanya perilaku korporasi yang tidak semata-mata menjamin adanya pengembalian kepada pemegang saham, upah bagi para karyawan, dan pembuatan produk serta jasa bagi para pelanggan, melainkan perusahaan bisnis juga harus memberi perhatian terhadap berbagai hal yang dianggap penting serta nilai-nilai masyarakat

\section{Faktor pendukung}

\section{Komitmen Pemerintah}

Peran BUMDes dalam mengembangkan usaha dan perekonomian masyarakat desa memerlukan penanganan yang komprehensif, sehingga tumbuhnya ekonomi nasional ditopang kokoh oleh perekonomian desa yang kokoh dan terarah.

Komitmen pemerintah terhadap keberlansungan BUMDes dibuktikan dengan pemberian dana dalam usaha mengembangkan BUMDes. Berdasarkan wawancara mendalam dengan EK (Staff Bidang Pemberdayaan Ekonomi Masyarakat Dan Tekhnologi Tepat Guna DPMD) pada tanggal 21 Juni 2019 menyebutkan bahwa peran pemerintah dalam penanggulangan kemiskinan dan pemberdayaan desa melalui BUMDes sangat tinggi. Ini dibuktikan dengan suntikan dana BUMDes berasal dari dana desa, APBD Kabupaten, APBD Provinsi dan kementerian terkait. Pemerintah sangat mendukung peningkatan kesejahteraan pada tingkat desa. Selain program BUMDes pemerintah melaksanakan programprogram lain yang berbasis pada masyarakat desa.

Keseriusan pemerintah daerah terhadap keberlansungan BUMDes pada kawasan pertambangan emas di Kabuapten Sumbawa Barat dengan memiliki sumber dana BUMDes (lampiran 1).

Peraturan Menteri Dalam Negeri Nomor 39 tahun 2010 tentang Badan Usaha Milik Desa, menyebutkan bahwa: untuk meningkatkan kemampuan keuangan pemerintah desa dalam penyelenggaraan pemerintahan dan meningkatkan pendapatan masyarakat melalui berbagai kegiatan usaha ekonomi masyarakat pedesaan, didirikan badan usaha milik desa sesuai dengan kebutuhan dan potensi desa.

Pernyataan ini diperkuat dengan hasil penelitian Ramadana dkk (2013) menjelaskan bahwa BUMDes ini merupakan usaha desa yang dibentuk/didirikan oleh pemerintah desa dimana kepemilikan modal serta pengelolaannya dilakukan oleh pemerintah desa dan masyarakat. BUMDes ini diharapkan dapat menstimulasi dan menggerakkan roda perekonomian di pedesaan.

\section{Tersedianya potensi Sumberdaya Alam}

Desa saat ini sudah diberikan kebebasan untuk mengatur wilayah, ekonomi dan masyarakatnya sendiri. Undang-Undang Republik Indonesia Nomor 6 Tahun 2014 Tentang Desa. Saat ini desa diberikannya kewenangan untuk mengatur wilayahnya sendiri, desa juga sudah dapat mengembangkan perekonomiannya sendiri. Ada banyak cara untuk mengembangkan ekonomi desa, salah satunya adalah melalui pemanfaatan aset desa sebagai potensi desa. Desa memiliki aset-aset asli desa yang dapat berbentuk tanah, kolam, sumber mata air ataupun sumber daya alam lainnya.

Keberadaan BUMDes sendiri memiliki tujuan yang diatur berdasarkan Peraturan Menteri Desa, Pembangunan Daerah Tertinggal, Dan Transmigrasi Republik Indonesia Nomor 4 Tahun 2015 tentang Pendirian, Pengurusan Dan Pengelolaan, Dan Pembubaran Badan Usaha Milik Desa. 
Keberadaan peraturan ini diperkuat dalam meningkatkan perekonomian desa, mengoptimalkan penggunaan aset desa dan meningkatkan usaha masyarakat dalam pengelolaan potensi ekonomi desa. Tujuan lain yang dapat dicapai oleh kehadiran BUMDes adalah mengembangkan rencana kerja sama usaha antar desa dan/atau dengan pihak ketiga, menciptakan peluang dan jaringan pasar yang mendukung kebutuhan layanan umum warga, membuka lapangan kerja, meningkatkan kesejahteraan masyarakat melalui perbaikan pelayanan umum, pertumbuhan dan pemerataan ekonomi desa, meningkatkan pendapatan masyarakat desa dan pendapatan asli desa

\section{SIMPULAN}

Berdasarkan hasil analisis data dalam kajian ini dapat disimpulkan diantaranya, yaitu: Faktor penghambat BUMDes pada kawasan pertambangan emas di Kabupaten Sumbawa Barat adalah: 1) faktor anggaran, 2) factor Sumberdaya Manusia pengelola, dan 3) Terbatasnya dukungan dari pihak swasta; Faktor pendukung sebagai penguat adalah 1) komitmen pemerintah, dan 2) tersedianya potensi Sumber Daya Alam; Keberadaan factor penghambat karena banyak program pemerintah yang dibiayai. Diperlukan kerja keras pengelola BUMDes dalam mengembangkan usaha melalui program-program kreatif dan inovatif untuk dapat berdaya saing.

\section{UCAPAN TERIMA KASIH}

Ucapan terima kasih terutama ditujukan kepada Kemenristek DIKTI yang telah memberikan dana Hibah Penelitian Terapan Tahun 3 (2019). Pihak-pihak yang membantu pelaksanaan penelitian dilapangan Bappeda dan Litbang Sumbawa Barat, BPMD KSB, Desa Se-Kecamatan Kawasan tambang, Pengelola BUMDes dan masyarakat.

\section{DAFTAR PUSTAKA}

Ibrahim \& Tanjung, S.I. (2018), Pengelolaan Badan Usaha Milik Desa Dalam Meningkatkan Kesejahteraan Masyarakat Perdesaan Kawasan Pertambangan Emas Di Kabupaten Sumbawa Barat, Jurnal Tata Loka, 20, (3), 309-316

Ibrahim, Kamaluddin, \& Mintasrihardi (2017). Persebaran Program Badan Usaha Milik Desa Di Kabupaten Sumbawa Barat. Prosiding. Seminar Nasional Pendidikan Ekonomi, Bisnis, Dan Keuangan. Universitas Sebelas Maret Surakarta

Ibrahim, Mintasrihardi, \& Djunaidi, A. (2017). Sinergisitas Program Badan Usaha Milik Desa Dalam Penang- gulangan Kemiskinan Di Kabupaten Sumbawa Barat. Prosiding. Seminar Nasional Geografi 2017. Jurusan Geografi Fakultas Ilmu Sosial Universitas Negeri Malang

Ibrahim, Mintasrihardi, Junaidi A. (2018) Karakteristik Badan Usaha Milik Desa Pada Perdesaan Kawasan Pertambangan Emas Di Kabupaten Sumbawa Barat. Prosiding. Seminar Nasional Asosiasi Sekolah Perencana Indonesia (ASPI) 2018

Ihsan, N.A. (2018). Analisis Pengelolaan Badan Usaha Milik Desa (BUMDes) Gerbang Lentera Sebagai Penggerak Desa Wisata Lerep, Journal of Politic and Government Studies, 7, (4), 221-230.

Ismail, S. (2011). Corporate Social Responsibility from Charity to Sustainability. Jakarta : Salemba Empat

Liow, H., Lengkong F.D.J. \& Novie, P. (2019). Implementasi Kebijakan Pengelolaan Badan Usaha Milik Desa Di Desa Tondegesan Kecamatan Kawangkoan. AP: Jurnal Administrasi Publik. 4, (61)

Meigawati, D, (2018), Implementasi Program Bumdes Di Kabupaten Sukabumi (Studi Kasus Desa Cisande Kecamatan Cicantayan), Konferensi Nasional Ilmu Administrasi

Mustanir, A., \& Darmiah, D. (2016). Implementasi Kebijakan Dana Desa Dan Partisipasi Masyarakat Dalam Pembangunan Di Desa Teteaji Kecamatan Tellu Limpoe Kabupaten Sidenreng Rappang. Jurnal Politik Profetik, 4, (2), 225-238

Mustanir, A., \& Jaya, I. (2016a). Pengaruh Kepemimpinan Dan Budaya Politik Terhadap Perilaku Pemilih Towani Tolotang Di Kecamatan Maritengngae Kabupaten Sidenreng Rappang. Jurnal Politik Profetik, 4, (1), 84-97

Mustanir, A., \& Jusman. (2016a). Implementasi Kebijakan Dan Efektivitas Pengelolaan Terhadap Penerimaan Retribusi Di Pasar Lancirang Kecamatan Pitu Riawa Kabupaten Sidenreng Rappang. Jurnal Ilmiah Akmen, 13, (3), 542-558

Mustanir, A., \& Lubis, S. (2017a). Participatory Rural Appraisal In Deliberations Of Development Planning. International Conference On Democracy, Accountability, And Governance (Icodag 2017) (Vol. 163)

Mustanir, A., Abadi, P., \& Nasri, A. (2016). Participation of Ethnic Community Towani Tolotang in Deliberation of Development Plan. In International Conference on Ethics in Governance (ICONEG 2016) (Vol. 84, pp. 356 - 359). Makassar: Atlantis Press. 
Mustanir, A., Yasin, A., Irwan, I., \& Rusdi, M. (2018). Potret Irisan Bumi Desa Tonrong Rijang Dalam Transect Pada Perencanaan Pembangunan Partisipatif. MODERAT: Jurnal Ilmiah Ilmu Pemerintahan, 4, (4), 1-14.

Peraturan Menteri Dalam Negeri Nomor 39 tahun 2010 tentang Badan Usaha Milik Desa

Peraturan Menteri Desa, Pembangunan Daerah Tertinggal, dan Transmigrasi No. 4 Tahun 2015 tentang Pendirian, Pengurusan, dan Pengelolaan, dan pembubaran Badan Usaha Milik Desa

Peraturan Pemerintah Nomor 72 Tahun 2005 tentang Desa

Ramadana., Berlian, C., Ribawanto, H. \& Suwondo. (2013). Keberadaan Badan Usaha Milik Desa (BUMDes) Sebagai Penguat Ekonomi Desa. Jurnal Administrasi Publik (JAP), 1, (6). 10681076.

Rani, S. (2018) Peran Dan Kontribusi Badan Usaha Milik Desa (Bumdes) Terhadap Kesejahteraan
Masyarakat Menurut Perspektif Ekonomi Islam (Study Pada BUMDes Karya Abadi Di Desa Karya Mulya Sari Kecamatan Candipuro Kabupaten Lampung Selatan) Skripsi, fakultas Ekonomi Dan Bisnis Islam Universitas Islam Negeri Raden Intan Lampung

Saepudin, E, Agustini, D.A. Agung, B. (2018). Partisipasi Masyarakat Ada Program Desa Mandiri Pangan Di Kabupaten Bandung. Sosiohumaniora, 20, (1), 86-94

Sutopo Dhanny S (2017) Kemiskinan Di Perdesaan Dalam Tinjauan Morfologi Sosial (Studi Kasus Kemiskinan Di Desa Sumber Salak Kecamatan Curahdami Kabupaten Bondowoso Jawa Timur). Sosiohumaniora, 19, (3), 268-273

Undang-Undang Nomor 32 Tahun 2004 tentang Pemerintahan Daerah

Undang-Undang Republik Indonesia Nomor 6 Tahun 2014 Tentang Desa 